International Journal of Current Micro6iology and Applied Sciences

ISSN: 2319-7706 Volume 10 Number 10 (2021)

Journal homepage: http://www.ijcmas.com

Original Research Article

https://doi.org/10.20546/ijcmas.2021.1010.067

\title{
Effect of Different Hormones on Disease Resistance against Bacterial Blight in Pomegranate
}

\author{
Mahesh S. Dashyal ${ }^{1 *}$, M. P. Basavarajappa ${ }^{1}$, G. Manjunath ${ }^{2}$, D. P. Prakash ${ }^{3}$, \\ Sayeed Wajeed R. Mulla ${ }^{4}$ and Anita Rajkumar Ghandhe ${ }^{5}$
}
${ }^{1}$ Department of Plant Pathology, College of Horticulture, University of Horticultural Sciences Bagalkot, 587104, Karnataka, India
${ }^{2}$ Department of Plant Pathology, College of Horticulture, University of Horticultural Sciences
Campus, Mysuru-571130, Karnataka, India
${ }^{3}$ Department of Fruit science, College of Horticulture, University of Horticultural Sciences
Campus, Koppal, Karnataka, India
${ }^{4}$ Department of Biotechnology and Crop Improvement HREC, Vijayapur, University of
Horticultural Sciences, Bagalkot 587104, Karnataka, India
${ }^{5}$ Department of Soil Science and Agriculture Chemistry, University of Horticultural Sciences, Bagalkot 587104, Karnataka, India
*Corresponding author

\section{A B S T R A C T}

Keywords

Fruit rind, seeds, Punica granatum, pomegranate

Article Info

Accepted:

18 September 2021

Available Online:

10 October 2021
Bacterial blight in pomegranate is a major disease caused by Xanthomonas axonopodis pv. punicae, which has resulted in significant economic losses in terms of both quality and quantity. The ineffectiveness of most chemicals in controlling this disease has shifted grower attention to the quest for a new molecule and hence the use of plant growth regulators and signaling molecules is a novel approach to control the disease as well as improving quality and quantity attributes of pomegranate. Hence, the aim of present study was to determine the impact of plant hormones like ethylene, jasmonic acid and salicylic acid on bacterial blight of pomegranate. Among different hormones applied, ethrel application shown maximum disease severity (33.2\%) and salicylic acid shown lowest disease severity (15.08\%) under greenhouse condition.

\section{Introduction}

Pomegranate (Punica granatum L.) belongs to family Lythraceae, an ancient favorite fruit of tropical and sub-tropical regions of the world. The fruit rind, seeds and pulp comprises of rich medicinal properties (Kirankumar et al., 2018). It is a native of Iran and it is widely cultivated throughout India, Iran, China, Turkey, USA, Spain, Azerbaijan, Armenia, Afghanistan, Uzbekistan, the Middle East, Pakistan, Tunisia, Israel, dry regions of 
Southeast Asia, Peninsular Malaysia, the East Indies and tropical Africa (Sharma et al., 2014). Punica granatum derived from two Latin words 'Pommum' (apple) and 'granatus' (grainy) literally means 'apple with many seeds'. Punica granatum with chromosome number $2 n=16$ or 18 is the only available cultivated species for commercial production (Shilkina, 1973). Pomegranate is considered as fruit of paradise because of its attractive colour, delicacy and has important dietary components (Ed Stover and Mercure, 2007). It is a good source of carbohydrates and minerals like calcium, iron and potassium and possess high pharmaceutical and therapeutic value. India is the major pomegranate growing country in terms of area and production.India contributes in the world pomegranate production with around 2.79 MT from the area of $0.25 \mathrm{M}$ ha (Anonymous, 2018-19). There has been a steady increase in area and production in the country and by the year 2025 , the area under pomegranate is projected to increase to 7.5 lakhs ha, from 1.25 lakhs ha at present (Pawar and Dingre, 2020). The leading pomegranate growing states of India are Maharashtra (70.2\%), Karnataka (10\%), Gujarat (7.4\%), Andhra Pradesh (6.7\%), Telangana (1.9\%), Madhya Pradesh (1.9\%), Tamil Nadu (1.0\%) and Rajasthan (0.4\%) (Khushboo and Desai, 2018).

Pomegranate crop has adaptability to a wide range of climatic conditions, hardy nature, low water requirement and good response to hitech practices, higher yield and returns on investment than many crops of dry regions of the world. Further, its therapeutic values and an increasing demand for table and processed products in local and export markets have made pomegranate a popular fruit of tropical and sub-tropical regions in the recent times (Sharma et al., 2014).

India is the largest producer of pomegranates in the world, but accounts only 7 per cent share of total world exports when compared with other countries (Ganeshkumar et al., 2016). Lack of adoption of modern technologies, improper training and pruning methods, nutrient and water management and problems like fruit cracking and pest, diseases are major bottlenecks for production of quality fruits.

Earlier pomegranate was less prone to pest and diseases, but due to recent advancements like mono culturing i.e., cultivation of pomegranate in large areas worldwide lead to emergence of new pest and diseases in severe form. Among them, bacterial and fungal diseases are prominent in pomegranate production regions, leading to considerable fruit losses throughout the growing season. Worldwide more than 55 pathogens have been reported to cause around 37 different diseases on pomegranate. The major ones in India are bacterial blight of pomegranate (caused by Xanthomonas axonopodis pv. punicae), wilt diseases (caused by Ceratocystis fimbriata alone and/or root-knot nematode Meloidogyne incognita), Phytophthora blight (Phytophthora spp.), fruit and leaf spots caused by fungal pathogens (Colletotrichum gloeosporioides, Cercospora punicae, Alternaria alternate) and fruit rots (including those caused by Aspergillus sp., Penicillium sp.) (Sharma et al., 2020).

Among many diseases and pests, bacterial blight (Xanthomonas axonopodis pv. punicae) is very devastating and has become an increasingly serious threat for pomegranate. For the first time in India, bacterial blight of pomegranate was reported by Hingorani and Mehta (1952). Presently it has a serious outbreak in all major pomegranate-growing states resulting in a major economic loss. The plant is susceptible to blight during all stages of growth and results in huge economic loss. In India, bacterial blight alone reduces the yield between 60 to 80 percent 
(Prasannakumar et al., 2020). Natural openings like stomata, hydathods, lenticels and nectarines become portals of entry to the bacterial pathogens. Small $(2-5 \mathrm{~mm})$ irregular water soaked lesions appear on leaves, later become dark brownish black with necrotic centre surrounded by yellow hallow. In advanced stages yellow hallow might not be visible; lesions may coalesce and often extend to veins and the midrib leads to premature leaf fall. Lesions on stem may girdle or break at the point of infection which prominently occur at nodes called as nodal blight. Water soaked symptoms appear at initial stage of fruit later increases its size, turn dark brownish black and cause necrosis. Later ' $L$ ' or ' $Y$ ' shape cracking leads to splitting of fruit makes it unfit for consumption and for market (Benagi and Kumar, 2011).

Pomegranate requires careful diagnosis and timely handling to protect the crops from heavy losses. Due to unavailability of resistant cultivar management of bacterial disease is becoming great challenge day by day.

Bacterial blight is deadly disease and management is really challenging and only option for this is integrated disease management. Most of the studies on pomegranate are aiming at management of pathogen with poor attention has been given to understand plant resistance. Further in plant array of signals, hormones, growth regulators are implicated in disease resistance.

In plant immune responses against diseases, plant hormones such as salicylic acid (SA), jasmonates (JAs) and ethylene (ET) act as signals to trigger and mediate a diverse array of defense responses (Spoel and Dong, 2008). However ethylene is one hormone has been used for different developmental and reproductive parameter manipulations. On other hand ethylene is implicated as hormone of disease resistance.
Management of disease involves the spraying of expensive chemicals which in turn increases the cost of pomegranate production and these chemicals are create residue in plant and soil thus, act as hazardous to environment. Antibiotics are becoming ineffective to the pathogen. Therefore, there is a need for development of an alternative eco-friendly measures and novel strategies are very much needed. Keeping all these aspects in view, the present investigation was undertaken.

\section{Materials and Methods}

In order to assess effect of different hormones, plants were sprayed with different hormones viz., ethylene 300ppm, salicylic acid 300ppm and jasmonic acid 300ppm (figure 1). After 24 hours of hormonal spray plants were inoculated with pathogen. After appearance of the symptoms one hundred leaves were collected randomly and graded using the severity scale given by Singh et al., (2015) and calculated the severity of bacterial blight and for each treatment three replications were maintained.

\section{Plants and growth conditions}

Experiments were conducted on six month old plants of cultivar Bhagwa in pots, filled with equal proportion of fine sand: garden soil: well decomposed farmyard manure. Experiments were performed in the green house where minimum and maximum temperatures ranged from $24^{\circ} \mathrm{C}$ and $29^{\circ} \mathrm{C}$; minimum and maximum relative humidity (RH) ranged from 30 per cent and 70 per cent, respectively.

\section{Bacterial strain and culture conditions}

$X$. axonopodis pv. punicae was multiplied on nutrient glucose agar and was grown at $28 \pm$ $1^{\circ} \mathrm{C}$ for $48-72 \mathrm{~h}$. For inoculum preparation, a loop full of bacterium was inoculated in 
nutrient glucose broth with constant shaking at $100 \mathrm{rpm}$. Bacterial suspension was diluted to $10^{7-8}$ cells per $\mathrm{ml}(\mathrm{OD} 600 \mathrm{~nm}=0.2)$ in various experiments.

\section{Pathogen Inoculation}

Three plants per treatment were spray inoculated with suspension of $X$. axonopodis pv. punicae and incubated further, under high humidity in polythene bags for $48 \mathrm{~h}$. The plants were observed at regular interval and data on incidence and severity of bacterial blight on leaves were recorded.

\section{Observations}

Disease severity was measured using following formula.

$$
\begin{aligned}
& \text { Per cent severity } \\
& \text { No. of infected leaves x Disease grade } \\
& \text { Total number of leaves x Max grade }
\end{aligned}
$$

Data analysis was done using completely randomized block design

\section{Results and Discussion}

Greenhouse experiment was carried out at Bio-control laboratory, UHS, Bagalkot to know the impact of different hormones on bacterial blight incidence. Three month older plants were taken for the experiment and 24 hours after hormonal spray, 48 hour older bacterial cultures were inoculated to different varieties of pomegranate plants. Hormones which are used in this study are ethrel (ethylene analog), salicylic acid and methyl jasmonate (jasmonic acid analog). After appearance of the symptoms disease was graded using the severity scale given by Singh et al., (2015) and calculated the severity of bacterial blight. The treatments were laid out in CRD with three replicate for each treatment.
Experimental analysis revealed that, among different hormones sprayed, ethrel sprayed at 300ppm (T1) shown maximum disease severity $(33.2 \%)$ when compared with water control (T4). Followed by, methyl jasmonate sprayed at 300ppm (T2) shown higher disease severity $(29.97 \%)$ but it is on par with water control $(27.32 \%)$ and ethanol control $(26.81 \%)$. Lowest disease severity was observed in T3 (Salicylic acid at 300ppm) (15.08\%) (Table 1).

Plant growth and response to environmental cues are largely governed by phytohormones. The plant hormones ethylene, jasmonic acid and salicylic acid (SA) play a central role in the regulation of plant immune responses (Denancé et al., 2013). Among different hormones sprayed, ethrel sprayed at 300ppm shown maximum disease severity $(33.2 \%)$ when compared with water control (T4). Similar observations are made by Rodrigues et al., (2020) were he observed Blast (Pyricularia oryzae) severity was higher on ethylene-sprayed plants regardless of the cultivar in wheat crop. Increase in ethylene concentration on plants induces their susceptibility against pathogens infection due to an acceleration on senescence, ripening and abscission of organs (Zhang et al., 2018).

Methyl jasmonate sprayed at 300ppm shown higher disease severity (29.97\%) but it is on par with water control $(27.32 \%)$ and ethanol control $(26.81 \%)$. It has been well known that $\mathrm{JA}$, as an activating signal molecule, triggers immunity to confer broad-spectrum resistance for plants (Okada et al., 2015). Pathogen infection or other forms of biotic attack stimulate rapid biosynthesis of JA and its derivatives, which would promote the expression of defense-related proteins and secondary metabolites such as alkaloids, terpenoids and PR proteins (Campos et al., 2014). For instance, some pathogens can activate the JA-signaling pathway to disable 
SA-mediated immune responses and, thus, facilitate pathogen proliferation (Brooks et al., 2005; Yang et al., 2017). Jasmonic acid appeared to contribute to citrus disease susceptibility by antagonizing SA-mediated effective defences against Xanthomonascitri subsp. citricausing citrus canker in citrus (Long et al., 2019). Susceptibility to Hyaloperonospora arabidopsidi inceases upon salicylic acid application in Arabidopsis. Coronatine (mimic molecule of jasmonic acid) involved in the elicitation of susceptibility to $P$. syringae by down-regulating SA-inducible defense response pathways via a SA/JA antagonism. Application of jasmonic acid (methyl jasmonate) increased the disease susceptibility (Cui et al., 2005). JA and Coronatine activate the expression of the NAC (transcription factor) tomato homolog, JASMONIC ACID2-LIKE. This transcription factor binds to and activates the expression of SAMT1 and SAMT2, which encode enzymes that deactivate SA by methylation, thereby suppressing the accumulation of SA and promoting stomatal opening (Du et al., 2014).

SA is a multifaceted hormone and is a key regulator in plant-pathogen signalling pathways thereby protecting abroad spectrum of pathogens (bacterial, viral, fungal etc.) (Vlot et al., 2009). It is observed that application of exogenous SA or increase in the level of endogenous SA is accompanied by a burst of reactive oxygen species such as $\mathrm{H}_{2} \mathrm{O}_{2}$, $\mathrm{O}_{2}$-etc (Shasmita et al., 2019). Results shown, lowest disease severity was observed in T3 (Salicylic acid at 300ppm) (15.08\%). Treatment of plants with salicylic acid has provided best protection to plants from bacterial blight disease (Xanthomonas oryzae pv. oryzae (Xoo)) thereby inducing resistance against the pathogen. Findings of Shasmita et al., (2019) suggested a rapid increase in defence enzyme (superoxide dismutase, catalase, peroxidase, polyphenol oxidase) activity and TP content of SA $(2 \mathrm{mM})$ treated plants as a result of a defence mechanism against Xoo. Similarly, Mondaland Shanmugam (2013) observed SA induced effective defense responses in tomato plants against $R$. solanacearum. The reduced disease incidence in tomato by SA may be a result of cell wall strengthening through deposition of lignin and induction of defense enzymes.

The majority of pomegranate farmers are in dire straits as a result of the bacterial blight disease, which has resulted in significant economic losses in terms of both quality and quantity. The ineffectiveness of most chemicals in controlling this disease has shifted growers' attention to the quest for a new molecule and hence the use of plant growth regulators and signal molecules may be a novel approach to controlling this disease as well as improving pomegranate quality and quantity. It is evident from the present studies that, foliar application of ethrel and jasmonic acid increased the disease severity of bacterial blight disease and meanwhile the application of salicylic acid reduced the disease severity.

\section{References}

Anonymous. 2018-19. Area and production of pomegranate in India. Ministry of Agriculture and farmers welfare, Government of India.

Benagi, V. I. and Kumar, R. M. R., 2011, Present status of pomegranate bacterial blight and its management. Acta Hort., 890: 475-480.

Campos, M. L., Kang, J. H. and Howe, G. A., 2014, Jasmonate-triggered plant immunity. J. Chem Ecol., 40(7): 657675.

Cui, J., Bahrami, A. K., Pringle, E. G., Hernandez-Guzman, G., Bender, C. L., Pierce, N. E. and Ausubel, F. M, 2005, Pseudomonas syringae manipulates systemic plant defenses against pathogens and herbivores. Proc. Natl. 
Acad. Sci., 102: 1791-1796.

Denancé, N., Sánchez-Vallet A., Goffner D. and Molina A., 2013, Disease resistance or growth: the role of plant hormones in balancing immune responses and fitness costs. Front. Plant Sci., 4: 155.

Du, M., Zhai, Q., Deng, L., Li, S., Li, H., Yan, L., Huang, Z. and Wang, B., 2014, Closely related NAC transcription factors of tomato differentially regulate stomatal closure and reopening during pathogen attack. Plant cell, 26(7): 3167-3184.

Ed Stover and Mercure, E. W., 2007, The pomegranate: A new look at the fruit of paradise. Hort. Science, 42 (5): 1 089-1092.

Ganeshkumar, R. D., Bhattacharyya, K., Narsimhaiah, L. and Santosh, Y. S., 2016, Performance of pomegranate export from India. Economic Affairs.,61(4): 575-580.

Hingorani, M. K. and Mehta, P. P., 1952, Bacterial leaf spot of pomegranate. Indian Phytopathol., 5: 55-56.

Khushboo, J. and Desai, N., 2018, Pomegranate the Cash Crop of India: A comprehensive review on agricultural practices and diseases. Int. J. Health Sci. Res., 8(5): 315-335.

Kirankumar, H., Shivakumara, B. S., Suresha, D. E., Madaiah, D. and Sarvjna, B. S., 2018, Effect of integrated nutrient management on quality and biochemical parameters of pomegranate $\mathrm{cv}$. Bhagwa under central dry zone of Karnataka. Int. J. Chem. Stud.,6(1): 05-06.

Long, Q., Xie, Y., He, Y., Li, Q., Zou, X. and Chen, S., 2019, Abscisic acid promotes jasmonic acid accumulation and plays a key role in citrus canker development. Front. Plant Sci., 10: 1634.

Mondal, K. K. and Shanmugam, V., 2013,
Advancements in the diagnosis of bacterial plant pathogens: An overview. Biotechnol. Mol. Biol. Review, 8(1): 1-11.

Okada, K., Abe, H. and Arimura, G., 2015, Jasmonates induce both defense responses and communication in monocotyledonous and dicotyledonous plants. Plant Cell Physiol., 56: 16-27.

Pawar, D. D. and Dingre, S. K., 2020, Productivity, water use, quality and economics of pomegranate fertigation in semiarid conditions of India. Int. J. Curr. Microbiol. App. Sci.,9(6): 25032510 .

Prasannakumar, M. K., Buela Parivallal, P. and Manjunatha, C., 2020, Loopmediated isothermal amplification assay for pre-symptomatic stage detection of Xanthomonas axonopodis pv. punicae infection in pomegranate. Australasian Plant Pathol.,49: 467473.

Sharma, J., Chandra, R., Babu, K. D., Meshram, D. T. and Maity, A., 2014, Pomegranate: Cultivation, Marketing and Utilization. Technical Bulletin No. NRCP/2014/1. ICAR-National Research Centre on Pomegranate, Solapur, Maharashtra.

Shasmita, Swain, H., Naik, S. K. and Mukherjee, A. K., 2019, Comparative analysis of different biotic and abiotic agents for growth promotion in rice (Oryza sativa L.) and their effect on induction of resistance against Rhizoctonia solani: a soil borne pathogen. Biol. Control, 133: 156-168.

Shilkina, I. A., 1973, On the xylem anatomy of the genus Punica L. BotanicheskiiZhurnal., 58: 1628-1630.

Singh, N. V., Abburi, V. L., Ramajayam, D., Kumar, R. and Chandra, R., 2015, Genetic diversity and association mapping of bacterial blight and other horticulturally important traits with 
microsatellite markers in pomegranate from India. Mol. Genet. Genomics, 290: 1393-1402.

Spoel, S. H. and Dong, X., 2008, Making sense of hormone crosstalk during plant immune responses. Cell Host Microbe.,3: 348-351.

Vlot, C., Dempsey, D. and Klessig, D., 2009, Salicylic acid, a multifaceted hormone to combat disease. Ann. Review Phytopathol.,47:177-206.

Yang, C., Li, W., Cao, J., Meng, F. and Yu,
Y., 2017, Activation of ethylene signaling pathways enhances disease resistance by regulating ROS and phytoalexin production in rice. Plant J., 89(2): 338-353.

Zhang, G., Sun, Y., Sheng, H., Li, H. and Liu, X., 2018, Effects of the inoculations using bacteria producing ACC deaminase on ethylene metabolism and growth of wheat grown under different soil water contents. Plant Physiol. Biochem., 125: 178-184.

\section{How to cite this article:}

Mahesh S. Dashyal, M. P. Basavarajappa, G. Manjunath, D. P. Prakash, Sayeed Wajeed R. Mulla and Anita Rajkumar Ghandhe. 2021. Effect of Different Hormones on Disease Resistance against Bacterial Blight in Pomegranate. Int.J.Curr.Microbiol.App.Sci. 10(10): 565571. doi: https://doi.org/10.20546/ijcmas.2021.1010.067 